\title{
Equity crowdfunding: A new phenomena ${ }^{1}$
}

\author{
Nir Vulkan \\ Said Business School \\ Oxford University \\ Thomas Åstebro \\ HEC Paris \\ Manuel Fernandez Sierra \\ Economics department \\ Oxford University
}

February 2016

\begin{abstract}
Crowdfunding has recently become available for entrepreneurs. Most academic studies analyse data from rewards-based (pre-selling) campaigns. In contrast, in this paper we analyse 636 campaigns, encompassing 17,188 investors and 64,831 investments between 2012 and 2015, from one of the leading European equity crowdfunding platforms. We provide descriptive statistics and carry out cross-campaign regression analysis. The descriptive statistics address its size, growth and geographic distributions in the UK. The regressions analyse which factors are associated with the probability of a successful campaign. We find some similarities and some interesting dissimilarities when comparing the descriptive statistics and regression results to research on rewards-based crowding. The data show that equity crowdfunding will likely pose great challenges to VC and business angel financiers in the near future. We discuss some research challenges and opportunities with these kind of data.
\end{abstract}

Keywords: equity crowdfunding, UK, campaign success.

\footnotetext{
${ }^{1}$ We are grateful to Carlos Silva, Duarte Henriques and especially Jeff Lynn from SEEDRS for their support and patience. Financial support from Nesta/Kaufman is gratefully acknowledged.
} 


\section{Introduction}

In recent years crowdfunding has emerged as a viable and popular alternative channel for entrepreneurs to fund their early stage businesses. The consultancy Massolution recently reported that funds raised via global crowdfunding expanded by 167 percent in 2014 to reach $\$ 16.2$ billion, up from $\$ 6.1$ billion in 2013 (Massolution, 2015). Massolution predicts that the industry is set to raise $\$ 34.4$ billion in 2015. A number of high profile campaigns and an increasing appetite to "cut out the middleman" mean crowdfunding is likely to remain an important part of early stage finance for some years to come.

Broadly speaking crowdfunding can be divided into four main categories: donations, rewards-based (also called pre-selling), lending, and equity crowdfunding. Rewards-based campaigns have proved extremely popular among entrepreneurs, growing in volume by an amazing 524 percent annually since 2009 (The World Bank, 2013). The focus of this paper, in contrast, is on equity crowdfunding. Here, the crowd, typically via an online platform, takes an equity stake in the business in much the same way VC funding works. Equity crowdfunding might be considered, a priori, to have a more difficult time catching on compared to the other crowdfunding models. This is the case since contracts associated with equity funding have been considerably more complicated than other types of funding, the due diligence process is often extensive, and the levels of investments have been so high that there is a strong preference for funders to intimately know the entrepreneur and their business (Gompers, P., 1995; Cumming et al., 2010). None of these characteristics seem at first blush to make equity investment amenable to online investing by the crowd, and, as a result, equity crowdfunding has been relatively rare worldwide, making up less than 5 percent of all crowdfunding investment by 2013 .

Nevertheless, data from Beauhurst, a leading consultancy on early stage investments in the UK, show that around 21 percent of all early stage investment and as much as 35.5 percent of all seedstage investment deals in the UK went through equity crowdfunding sites in 2015 (Beauhurst, 2015). These data reflect a rapid recent growth that is challenging the existing Angel networks and even some VCs.

The UK has been the fastest growing country for equity crowdfunding campaigns in the world, both in terms of their number and size. This is mainly due to a clear regulatory framework that has been in place since the end of 2011, which has given UK based platforms a head start. By contrast, the regulatory framework for equity crowdfunding in the US, lay down under the Title III of the JOBS act of 2012, was only approved by the Securities and Exchange Commission in the fall of 2015. Moreover, investors of start-ups in the UK also benefit from a very generous tax incentive via the Seed Enterprise Investment Scheme (SEIS) and the Enterprise Investment Scheme (EIS). Both schemes are designed to help small UK-based companies raise finance by offering tax relief on new shares in those companies. ${ }^{2}$ For these reasons, recent experience in the UK provides us with a unique opportunity to explore the properties of equity crowdfunding, and to make some preliminary forecasts about what will likely happen in the US in the near future.

\footnotetext{
${ }^{2}$ The EIS is aimed at wealthier investors who receive $30 \%$ tax relief, but whose investments cannot be sold or transferred for a minimum lock-in period of three years. The SEIS is more generous and provides tax relief of up to $50 \%$ on investments of up to $f 100,000$, and capital gains tax exemption.
} 
In this paper we study a unique dataset kindly shared with us by SEEDRS, one of the leading UK equity crowdfunding platforms. SEEDRS was founded in 2012 by Jeff Lynn and Carlos Silva, and was the first equity crowdfunding platform to be accepted as a member of the UK Business Angels Association. More recently SEEDRS has announced their expansion to the US market via the acquisition of Junction Investments in California. SEEDRS business model is based on taking a one-off fee of up to 7.5 percent from successfully funded businesses. In addition, SEEDRS takes a success fee from investors equal to 7.5 percent of the profits made as a result of their investment.

We analyse 636 equity crowdfunding campaigns, encompassing 17,188 investors (also called "backers") and 64,831 investments (often termed "pledges") between 2012 and 2015. We provide descriptive statistics and carry out various regression exercises to analyse which factors are associated with the probability of a successful equity crowdfunding campaign. Such analysis have been performed before (e.g. Mollick, 2014), but mostly on rewards-based campaigns. ${ }^{3}$ Throughout this paper we use Mollick's results as a benchmark to ours, not only because his was the first major paper on the subject, but more importantly because to a large extent his results have already been replicated by Colombo et al (2015) and by Kuppuswamy and Bayus (2015) looking at Kickstarter. The focus on rewards-based crowdfunding has been driven by the availability of data from sites such as Kickstarter and Indiegogo, ${ }^{4}$ and because regulation in the US for equity based crowdfunding has been lacking until very recently.

Making some cautious predictions about the nature of crowdfunding across the different models, Mollick (2014) states that "...to some degree, all crowdfunding funders may be thought of as investors, making decisions about which projects to support based on their expectations for success...", further arguing that "...the dynamics of crowdfunding may be stable across some contexts. (page. 4)." We use the data from SEEDRS to address these predictions in a way that has not been possible before.

We find that equity crowdfunding differs from the typical rewards-based crowdfunding in a number of important respects: a) a much higher average amount pledged; b) a much higher average campaign goal, steadily increasing over time and lately approaching the size of first round investments for VCs; c) the existence of (pre-money) valuation of each of the projects, and d) the clear goal of the backers to obtain a positive monetary return on their investment. In terms of the geographical distribution, we find that the majority of the investors using the platform are located in the London area. There is, however, considerable geographical dispersion of backers across the country, which is indicative that equity crowdfunding could mitigate the effect that distance has on traditional fundraising efforts (see, for example, Agrawal (2011)). The data from SEEDRS, while limited to one platform, albeit a very important European one, suggests that equity crowdfunding will become a significant phenomenon for early stage fundraising in the US in years to come, potentially surpassing rewards-based crowdfunding.

We further discover that the dynamics of investments during a campaign, and in particular the kind of herding behaviour observed in the early stages of a campaign, do seem to be similar in both

\footnotetext{
${ }^{3}$ In the recent literature review by Belleflamme et al. (2015) we found 13 references to papers on rewardsbased crowdfunding, 12 papers on lending, 3 on donations, and only 2 on equity crowdfunding.

${ }^{4}$ see Agrawal et al (2011, 2014), Belleflamme et al (2014), Mollick (2014), Zhang and Liu (2012) to name a few
} 
equity and rewards-based crowdfunding. After we present the data and analysis, we provide a more detailed discussion of the similarities and differences between the different types of crowdfunding.

\section{Data Description and Variables}

The data used for the analysis comes from the equity crowdfunding platform SEEDRS. The information was made available directly from their СТO and comprises the full universe of campaigns from the launch of the platform in July 2012 up until September 2015. In total, there are 636 campaigns, 17,188 investors and 64,831 pledges.

For each project, the raw data contains information about the date the campaign started raising funds, the declared investment target, the pre-money valuation of the company, the number of entrepreneurs, and the timing and value of each of the pledges received while the campaign was running. Each pledge is also matched to a specific investor with a unique identifier, so we are able to analyse the behaviour of both individual campaigns and individual investors. The key variables of interest at the campaign level are summarized in Table 1 , where the variables are defined in Table 2.

\section{Results}

The descriptive statistics presented in Table 1 provide a first glimpse into the characteristics of the projects aiming to raise capital through the SEEDRS platform. Out of the 636 campaigns for which information is available, 216 (33.9 percent) ended up being successful in raising the declared investment goal. We divide the summary statistics of the variables used into three groups, corresponding to the overall mean across all campaigns, and the averages within the group of successful and unsuccessful campaigns separately.

The average campaign goal was $f 138,228$, but there is a large heterogeneity in the amounts asked by individual projects, with desired investments that range from $£ 2,500$ to more than $£ 1,000,000$. Moreover, the amount of capital sought by individual campaigns has grown considerably as SEEDRS has consolidated since their beginning in 2012. During the first year of operation, the average desired investment of a campaign was close to $f 68,000$, but this number increased to more than $£ 200,000$ during the last 12 months for which data is available (see Figure 1). This desired investments corresponds to an average equity offered (in pre-money valuation terms) of about 12.6 percent. The levels of investments sought and the pre-money valuations of the campaigns in SEEDRS present a first sharp contrast with other non-equity crowdfunding schemes. For example, Mollick (2014) in a study of more than 48,500 projects raising funds in Kickstarter, shows that the average goal of the campaigns in that platform is less than 10,000 USD, considerably lower than what is observed in our sample.

Although there are substantial differences in the scale of the campaigns between equity and nonequity crowdfunding platforms, we find that some of the dynamics of investment behaviour are 
consistent with what has been found in other studies of non-equity crowdfunding models. ${ }^{5}$ For example, the data shows that funding is highly skewed, with successful campaigns receiving almost all of the total amount pledged each month (see Figure 2). Campaigns that fail to raise the desired capital tend to do so by a large margin, while most successful campaigns overfund, going up to 138 percent of the target. The SEEDRS platform allows the companies who succeed in meeting their target to accept more funds at the same rate of equity as originally offered, and this particular feature is proving popular with roughly 61.3 percent of the companies.

Also consistent with previous analysis of non-equity crowdfunding platforms is the importance of early investments in determining the chance that a campaign has of reaching the goal. Successful campaigns accumulate, on average, 17.5 percent of the total investment sought at the end of the first day, and this number increases to 51.2 percent after the first week. Failed campaigns, on the other hand, never really get started. Halfway through the time limit unsuccessful campaigns have only covered about 11.1 percent of the goal. This pattern is better illustrated in Figure 3 , where we plot the timing it takes for campaigns to reach a given share of the target within the first 30 days of a maximum allowed 60 day campaign period. The Figure is divided in 4 parts, each corresponding to a different distributional statistic (10th, 50th, 90th percentiles, and the mean). It is clear that even the most successful group within failed campaigns barley managed to raise half of the desired capital by day 30.

The ability of successful campaigns to attract a large number of investors contrasts with the lack of supporters for campaigns that end up failing the mark (see Figure 4). Successful campaigns have an average of 158 backers, more than five times the average number of investors in failed campaigns. The difference is not limited to the number of investors. The typical contribution made by each backer is larger for successful campaigns, with a median pledge of $£ 368$ compared to $£ 233$ for failed campaigns. Average individual contributions have also increased substantially in time. The average pledge in 2012 was $£ 400$, while in the first 7 months of 2015 the same number is close $£ 1,400$ (see Figure 5).

Moreover, a few large investments appear to have a major role in driving the success. The largest pledge in a successful campaign accounts for about 30 percent of the total investment sought, which is significantly larger than the 5.4 percent contribution of the highest pledge in an unsuccessful project. Large pledges can be important in two ways: by contributing to the accumulated capital stock of the campaign, and by their indirect effect in incentivizing other backers into investing in a particular project. Each individual campaign raising capital through SEEDRS provides information about both the cumulative amount of funds raised up to that point in time and their top investors in terms of the value of the pledges ${ }^{6}$. Having backers willing to invest large sums in a campaign can act as a positive signal to undecided investors about the potential quality of a project, and this indirect effect is more relevant in the context of high uncertainty that is intrinsic to crowdfunding markets.

In terms of the characteristics of the supporters of the campaigns, about half of the investors making a pledge to a project decide not to allow their profiles to be seen by others. Investor profiles vary in their information content, but they include their geographic location, previous investments in other

\footnotetext{
${ }^{5}$ See, for example, Agrawal et al., 2011; Agrawal et al., 2014; Mollick, 2014.

${ }^{6}$ Each campaign reports all the pledges made to the project, but investments are organized by their magnitude, so that top pledges are shown first in the campaign's page.
} 
campaigns, and, on some occasions, social media contacts or short biographic descriptions. The lack of information about who is supporting a project can add to the uncertainty, but it appears to make little difference in determining the probability of success ${ }^{7}$. Apart from this, projects that end up reaching the target do tend to attract investors with a better success history within the platform, as well as those that have invested large amounts in previous projects.

In each calendar month, about 8.5 percent of the running campaigns reach their target, but the success rate has doubled in time from 5 percent in the first year of operation of SEEDRS to more than 11 percent in the last 12 months (see Figure 6). In order to get a better sense of the relative importance of different campaign characteristics for the probability of success, we estimate a linear probability model ${ }^{8}$ using the dichotomous success indicator as a dependent variable, and the campaign characteristics as covariates. Results of the regression exercise are shown in Table 3. The four factors that are more strongly associated with the probability of success are: (1) the share accumulated in the first week of the campaign ${ }^{9} ;(2)$ the investment goal set by the promoters ${ }^{10} ;(3)$ the largest amount pledged by a single backer; and (4) the number of backers in the campaign. An increase of one standard deviation in any of these indicators increases (or decreases in the case of the investment target) the probability of success by between 11 and 18 percentage points. Given a baseline success share of 33.9 percent, these results suggest that the dynamics of any of these four variables is crucial for the end result of the campaign.

The first column of Table 4 shows the results of an alternative regression specification, where we use the percentage of the investment sought that each campaign was able to raise as the dependent variable instead of the success indicator. Results are mostly unchanged, with the same four factors having the strongest effect on the actual amount raised by the campaigns. In particular, an increase of one standard deviation in any of these variables increases (or decreases) the average share raised by between 22 and 27 percentage points. In the next five columns of Table 4 we look at the extent to which the independent variables are related to campaign performance at other points of the distribution beyond the mean. For this purpose we run a set of quantile regressions based on a similar specification as the one used in first column. The results show that having a strong start has a large and positive effect across the performance distribution, but that this is not necessarily the case with the other three main factors. A larger investment goal reduces the percent raised mostly for top performing campaigns (above the 50th percentile), and a similar pattern is observed for both the impact of top pledges and number of backers. These results accentuate how important is for a campaign to have a strong start, but show that other factors only have a significant role once a campaign has gained some traction.

It is not easy to disentangle the underlying mechanism driving these reduced form results. For example, it is likely that a good start of a campaign can be interpreted by other backers as a positive signal about the unobserved underlying quality of the project, driving other investors into the

\footnotetext{
${ }^{7}$ Kim and Viswanathan (2014), studying an online crowdfunding market for mobile applications, find that the identity of early investors, especially information about their previous experience, can positively influence the subsequent behavior of other investors.

${ }^{8}$ As shown in Table A1 in the Appendix, results are unchanged if we instead fit a probit model.

${ }^{9}$ Results are robust to using other time spans in the regressions (e.g. percent covered in a day or in a month).

${ }^{10}$ Ultimately, the decisions on how much money to ask for and at what pre money valuation lies with the entrepreneurs, not SEERDS. Whilst we are very curious about this difference in valuation between successful and unsuccessful projects, there is nothing in the data we have that allows us to get to the cause of this.
} 
campaign. This herd type of behaviour has been extensively analysed in theoretical models and empirical work on financial markets (see, among others, Banerjee (1992), Welch (1992), Chari and Kehoe (2004), Zhang and Liu (2012)), and can be important in a market with such large information asymmetries as equity crowdfunding. A complementary explanation is that promoters that have early success are those that put a larger effort into finding investors even before the official start of the campaign. For example, SEEDRS explicitly advises promoters to do extensive pre-launch marketing, and allows a campaign to have a web page with a private URL before the campaign goes public.

In Table 5 we present a regression exercise that aims to get an idea of what factors are more strongly associated with a good start of a campaign. In this regressions we use the share of the goal covered in the first week as the dependent variable, and the set of predetermined campaign specific variables and early performance indicators as covariates. Campaigns with a higher investment goal, and those offering a larger equity stake, tend to have a slower relative start. In terms of other determinants of within period dynamics, we find that accumulating a larger mass of investors and finding individual backers willing to make high-valued pledges ${ }^{11}$ have strong positive effects in the early stages of a campaign.

More research focusing on early campaign dynamics is necessary to understand what factors are driving these results. In any case, it appears that the type and quality of the information that investors can infer from the campaign, and from the actions of other backers, is central to the story. As we discussed before, having individuals willing to commit large sums of money can help a campaign by signalling to other investors about the willingness to participate in a project. It is also interesting that variables like the previous relative success rate of the backers, and having investors in the campaign from the top 1 percent of overall successful investors, are both statistically significant, but of second order importance in driving overall campaign success (see Table 3). Both of these variables might act as visible proxies of the type of backers that a campaign is attracting, which in turn can trigger and reinforce positive dynamics. Their impacts on herding behaviour might be better analysed within campaigns over time instead of across campaigns.

\section{Discussion}

In this paper we provide the first detailed study of equity crowdfunding in the UK. Equity crowdfunding is an important and fast growing economic phenomenon. It has already had a significant impact on early stage funding in the UK, and is likely to become an important avenue for entrepreneurial finance in years to come in the US

Our data shows that on one leading UK platform, significantly more and substantially larger projects are funded via equity crowdfunding in 2015 than at the start in 2012. Overall market data show less detail, but the same trends are visible there as well (e.g. Beauhurst, 2015). Our data show that a large number of successful campaigns are overfunded - sometimes by more than twice the amount originally requested. We find that, in order to succeed in reaching the project's target on time, it is

\footnotetext{
${ }^{11}$ We create a dichotomous indicator to identify single large pledges. The indicator takes a value of one if at least one backer during the first week has made a pledge of at least $£ 2,500$ pounds, and zero otherwise. This value corresponds to the 95 percentile of the distribution of pledges.
} 
particularly important to start strong, to have many backers, and especially to have (at least) one backer who provides a large pledge.

Our findings are largely consistent with Agrawal et al.'s (2014) seven-point characterization of the economics of crowdfunding, which was mostly based on empirical work focusing on non-equity crowdfunding platforms, in particular the idea that "funding propensity increases with accumulated capital and may lead to herding". Our data combined with the data collected by Beauhurst (2015) are also consistent with their suggestion that crowdfunding will substitute traditional sources of financing.

Our paper's most immediate comparison is Mollick (2014), which studies the underlying dynamics of rewards-based and patronage crowdfunding, using data from Kickstarter. We find that (a) the average investment goal is substantially lower in Kickstarter: $\$ 9,866$ US dollars compared with 138,000 pounds sterling among SEEDRS projects; (b) the average pledge, in particular on the successfully completed campaigns, is substantially greater on SEEDRS (1,370 pounds) than on Kickstarter (\$80); (c) Mollick found that funded projects achieve 1.5 times their goal on average, which is very close to our figure of 138 percent; (d) unsuccessful campaigns fail by large margins on both Kickstarter and SEEDRS; (e) projects on SEEDRS have a lower success rate compared with Kickstarter: 33.9 percent success rate on SEEDRS versus almost 50 percent in Kickstarter; (f) the average number of backers per campaign is approximately the same, 67 on Kickstarter and 71 on SEEDRS, although SEEDRS have somewhat more backers on the successful campaigns than Kickstarter and finally (g) increasing goal size is negatively related with success probability on both platforms. Similarly to Agrawal et al. (2011) and Mollick (2014), we find significant geographical dispersion among investors using the SEEDRS platform in the UK (see Table 6). Close to 25 percent of both backers and pledges, and 38.58 percent of the funds, originate in the London region. But the rest of investors and funds are largely dispersed across the country, proving further evidence to the assertion that crowdfunding platforms can overcome the distance related frictions that characterize venture capital financing.

Although there are indeed some similarities across Kickstarter and SEEDRS as representatives of prominent rewards-based and equity crowdfunding platforms, the differences observed nevertheless lead us to conclude that equity crowdfunding is going to be a new and substantially different fundraising phenomena than rewards-based crowdfunding. Equity crowdfunding has some commonalities in data more similar to business angel and early stage venture capital than to rewards based crowdfunding, in particular: the average size of the more recent campaigns; the presence of a pre-money valuation; and the fact that there is an expressed equity sharing deal for each pledge. Nevertheless, crowdfunding is distinctly different from traditional forms of financing in that the contracts are standardized and considerably simpler, the information provision is less, the number of investors are much larger, and the fundraising process is much shorter. Given the increases in efficiency of the fundraising process from the entrepreneurs' perspective, it is not surprising that equity crowdfunding has gathered such a momentum in recent years.

Herding is common in all types of crowdfunding. It is what we expect in a situation with so much uncertainty: the decisions of the crowd provide some information in the absence of much else. There have been a number of recent studies which use data from crowdfunding to specifically study 
the dynamics of herding in these markets: Zhang and Liu (2012) who use P2P lending data and more recently Kim et al (2015) who use rewards-based crowdfunding data.

In a companion paper (Astebro et al., 2015) we look in more detail at the question of herding. For a given campaign we study the reaction of investors to high value pledges (over 1000 pounds) and the rank ordering of the pledges on the platform. This allows us to separate rational from irrational herding and test which is more persistent. More research on this topic is sorely needed.

Another line of research we are exploring with these data is overfunding. Entrepreneurs are clearly under pressure to set a realistic target, one that they can achieve. But accepting additional monies is expensive compared to closing the campaign at the goal and obtaining the same funds in the next financing round, if they make it. In a future paper we build a simple model which captures this dilemma and tests it against the SEEDRS data.

The data from the UK at large so far has not indicated spectacular lawsuits or other clear signs of market failures, although detailed analysis of new microdata may conclude that additional regulatory adjustments could still be warranted. For example, if irrational herding tendencies appear too strong, regulators might consider tightening requirements for investor's financial knowledge, given the size and development of the sector. Regulators are keeping a keen eye on further developments.

Finally, the real measurement of success for equity crowdfunding would of course be the actual success of the companies that uses it in the years to come. Interesting therefore to note, that in the latest communication from Beauhurst (Beauhurst 2016), some very positive news on equity crowdfunding emerge: Beauhurst looked at 'trouble rate' (by looking at their status in the companies house register) of all companies that secured seed-stage equity investment through crowdfunding platforms since 2012. They find (1) a 20.9\% drop in the trouble rate of companies which received equity crowdfunding at seed-stage, between 2013 and 2014, and (2) that the 2015 trouble rate of seed-stage crowdfunded companies was actually lower than the trouble rate of those that received any form of investment at seed stage. While these are still early days, this is a strong indication that equity crowdfunding is more than a fade and is likely to remain an important aspect of early stage finance for years to come.

\section{Conclusions}

Equity crowdfunding is likely to be the subject of many research papers in finance and management in the coming years, and rightly so given the amounts involved and the impact on early stage financing. We hope this paper can provide the first useful evidence for researches working in this space. 


\section{Tables and Figures.}

Table 1: Summary statistics

\begin{tabular}{|c|c|c|c|c|}
\hline & All & Successful $(33.9 \%)$ & Unsuccessful & Difference \\
\hline \multicolumn{5}{|l|}{ Campaigns } \\
\hline Pre-money valuation (mean) & $\begin{array}{c}1,446,685 \\
(4,954,847)\end{array}$ & $\begin{array}{c}2,235,405 \\
(7,523,961)\end{array}$ & $\begin{array}{c}1,044,741 \\
(2,798,181)\end{array}$ & $1,190,664$ \\
\hline Pre-money valuation (median) & 599,626 & 803,292 & 509,867 & 293,426 \\
\hline Equity offered (mean) & $\begin{array}{c}12.6 \\
(8.12)\end{array}$ & $\begin{array}{c}9.7 \\
(6.99)\end{array}$ & $\begin{array}{c}14 \\
(8.26)\end{array}$ & -4.35 \\
\hline Equity offered (median) & 10 & 9.09 & 11.3 & -2.16 \\
\hline Campaign goal (mean) & $\begin{array}{c}138,228 \\
(282,465)\end{array}$ & $\begin{array}{c}160,307 \\
(285,140)\end{array}$ & $\begin{array}{c}126,874 \\
(280,745)\end{array}$ & 33,433 \\
\hline Campaign goal (median) & 77,187 & 78,520 & 76,958 & 1,562 \\
\hline \% Raised & $\begin{array}{c}56.5 \\
(70.3)\end{array}$ & $\begin{array}{l}138 \\
(62)\end{array}$ & $\begin{array}{c}15.2 \\
(20.7)\end{array}$ & 123 \\
\hline \# Entrepreneurs & $\begin{array}{c}2.86 \\
(1.75)\end{array}$ & $\begin{array}{c}3.42 \\
(1.99)\end{array}$ & $\begin{array}{c}2.57 \\
(1.54)\end{array}$ & .85 \\
\hline EIS tax relief & $\begin{array}{l}.269 \\
(.444)\end{array}$ & $\begin{array}{c}.398 \\
(.491)\end{array}$ & $\begin{array}{c}.202 \\
(.402)\end{array}$ & .20 \\
\hline SEIS tax relief & $\begin{array}{c}.649 \\
(.478)\end{array}$ & $\begin{array}{l}.528 \\
(.5)\end{array}$ & $\begin{array}{c}.712 \\
(.453)\end{array}$ & -.18 \\
\hline \# Backers & $\begin{array}{c}71 \\
(114)\end{array}$ & $\begin{array}{c}158 \\
(157)\end{array}$ & $\begin{array}{c}27 \\
(35.6)\end{array}$ & 131 \\
\hline \# Pledges & $\begin{array}{l}80.5 \\
(131)\end{array}$ & $\begin{array}{c}179 \\
(180)\end{array}$ & $\begin{array}{c}29.7 \\
(39.2)\end{array}$ & 149 \\
\hline \multicolumn{5}{|l|}{ Investments } \\
\hline Share public pledges & $\begin{array}{c}.511 \\
(.202)\end{array}$ & $\begin{array}{c}.474 \\
(.101)\end{array}$ & $\begin{array}{c}.53 \\
(.235)\end{array}$ & -.06 \\
\hline Backer success share & $\begin{array}{c}.304 \\
(.198)\end{array}$ & $\begin{array}{c}.395 \\
(.185)\end{array}$ & $\begin{array}{c}.258 \\
(.189)\end{array}$ & .14 \\
\hline Backer in top $1 \%$ & $\begin{array}{l}.0456 \\
(.209)\end{array}$ & $\begin{array}{c}.12 \\
(.326)\end{array}$ & $\begin{array}{l}.00714 \\
(.0843)\end{array}$ & .11 \\
\hline Mean amount pledged & $\begin{array}{c}895 \\
(2,184)\end{array}$ & $\begin{array}{c}1,370 \\
(2,470)\end{array}$ & $\begin{array}{c}655 \\
(1,984)\end{array}$ & 715 \\
\hline Median amount pledged & $\begin{array}{c}279 \\
(1,861)\end{array}$ & $\begin{array}{c}368 \\
(1,996)\end{array}$ & $\begin{array}{c}233 \\
(1,790)\end{array}$ & 135 \\
\hline Amount pledged / goal & $\begin{array}{c}.01 \\
(.0416)\end{array}$ & $\begin{array}{c}.019 \\
(.0696)\end{array}$ & $\begin{array}{c}.005 \\
(.00977)\end{array}$ & .013 \\
\hline Max pledge & $\begin{array}{c}22,798 \\
(68,420)\end{array}$ & $\begin{array}{c}48,755 \\
(103,253)\end{array}$ & $\begin{array}{c}9,634 \\
(33,920)\end{array}$ & 39,121 \\
\hline Max pledge / goal & $\begin{array}{c}.135 \\
(.193)\end{array}$ & $\begin{array}{l}.296 \\
(.24)\end{array}$ & $\begin{array}{c}.0537 \\
(.0852)\end{array}$ & .24 \\
\hline \multicolumn{5}{|l|}{ Timing } \\
\hline$\%$ Covered in day 1 & $\begin{array}{c}7.2 \\
(17.8)\end{array}$ & $\begin{array}{c}17.5 \\
(26.7)\end{array}$ & $\begin{array}{l}1.9 \\
(5.8)\end{array}$ & 15.6 \\
\hline$\%$ Covered in week 1 & $\begin{array}{c}20.8 \\
(36.6)\end{array}$ & $\begin{array}{c}51.2 \\
(48.7)\end{array}$ & $\begin{array}{c}5.13 \\
(9.69)\end{array}$ & 46.1 \\
\hline$\%$ Covered in month 1 & $\begin{array}{c}39.2 \\
(56.2) \\
\end{array}$ & $\begin{array}{c}93.8 \\
(65.3) \\
\end{array}$ & $\begin{array}{c}11.1 \\
(16.2) \\
\end{array}$ & 82.8 \\
\hline Observations & 636 & 216 & 420 & \\
\hline
\end{tabular}

Notes: standard deviation in parenthesis. All values are expressed in real GBP of January 2015. Each cell is computed by taking the average across the campaigns in the respective column groups. The variables capturing the pre-money valuation, equity offered and campaign goal include both the mean and the median across campaigns. 
Table 2: Definitions of Variables

\begin{tabular}{|c|c|}
\hline Variable & Definition \\
\hline $\begin{array}{l}\text { Successful } \\
\text { campaign }\end{array}$ & $\begin{array}{l}=1 \text { if the campaign goal was met, zero otherwise. SEEDRS is an "all or nothing" platform in } \\
\text { which projects have up to } 60 \text { days to raise investment, so companies only receive funding if } \\
\text { they reach the declared investment goal within the time limit. }\end{array}$ \\
\hline $\begin{array}{l}\text { Pre-money } \\
\text { valuation: }\end{array}$ & The self-reported pre-money valuation of the project. \\
\hline Equity Offered & Percentage of equity that the campaign managers are offering. \\
\hline Campaign goal & Declared desired investment by the campaign promoters. \\
\hline \% Raised & $\begin{array}{l}\text { Total amount raised by the campaign divided by the campaign goal. SEEDRS allows } \\
\text { campaign promoters to accept more capital than what they had originally asked for, so they } \\
\text { can "overfund" the projects once the target is reached. In cases in which there is } \\
\text { overfunding, the variable takes a value that is greater than } 100 \text { percent. }\end{array}$ \\
\hline \# Entrepreneur & Number of entrepreneurs in charge of the project. \\
\hline EIS tax relief & $\begin{array}{l}=1 \text { if investors in the campaign have access to the Enterprise Investment Scheme (EIS) tax } \\
\text { relief, zero otherwise. }\end{array}$ \\
\hline SEIS tax relief & $\begin{array}{l}=1 \text { if investors in the campaign have access to the Seed Enterprise Investment Scheme } \\
\text { (SEIS) tax relief, zero otherwise. }\end{array}$ \\
\hline \# Backers & Number of different investors that have made pledges to the campaign. \\
\hline \# Pledges & Number of different pledges made to the campaign. \\
\hline $\begin{array}{l}\text { Share of public } \\
\text { pledges }\end{array}$ & $\begin{array}{l}\text { Investors can choose to share their SEEDRS' profile with other members of the platform. } \\
\text { Each profile includes information about the investor location, the amount they have } \\
\text { invested in different projects within the platform, campaigns in which they are promoters, } \\
\text { and, occasionally, social media contacts or short biographic descriptions. Each pledge made } \\
\text { is recorded in the campaign's page in order of magnitude, and investors are asked if they } \\
\text { want their profiles to be seen next to the value of the investment. The variable is then } \\
\text { constructed as the ratio between investments that are public, that is, investments in which } \\
\text { the backer profile is available to the public, and total investments made in a given } \\
\text { campaign. }\end{array}$ \\
\hline $\begin{array}{l}\text { Backer success } \\
\text { share }\end{array}$ & $\begin{array}{l}\text { For each investor making a pledge in a project, we calculate the ratio between previous } \\
\text { successful campaigns in which the backer has invested and the total number of previous } \\
\text { campaigns (successful or not) in which he or she made pledges. In cases in which the } \\
\text { investor has not made pledges in previous projects the ratio takes the value of zero. The } \\
\text { variable is then constructed as the average success share across all backers in the campaign. }\end{array}$ \\
\hline $\begin{array}{l}\text { Backer in top } \\
1 \%\end{array}$ & $\begin{array}{l}\text { Before the start date of each campaign, we rank investors into percentiles according to the } \\
\text { average value of the pledges they have made in all previous successful campaigns. If an } \\
\text { investor that is ranked in the top } 1 \% \text { makes a pledge in the campaign, the variable takes a } \\
\text { value of one, if not, the variable takes a value of zero. }\end{array}$ \\
\hline $\begin{array}{l}\text { Amount } \\
\text { Pledged }\end{array}$ & Average value in pounds of the pledges made to the campaign. \\
\hline $\begin{array}{l}\text { Amount } \\
\text { Pledged /goal }\end{array}$ & Average campaign pledge in pounds divided by the campaign goal. \\
\hline Max pledge & Maximum single pledge made in each campaign. \\
\hline $\begin{array}{l}\text { Max pledge / } \\
\text { goal }\end{array}$ & Maximum single pledge made divided by campaign goal. \\
\hline $\begin{array}{l}\text { Self- } \\
\text { investment }\end{array}$ & $=1$ if the project promoters made an investment to the project, zero otherwise. \\
\hline$\%$ Covered $X$ & he campaign goal that was raised during a given period $(X)$ of time. \\
\hline
\end{tabular}


Table 3: Probability of success. Linear Probability Model

\begin{tabular}{|c|c|c|c|c|c|c|c|c|}
\hline & \multicolumn{8}{|c|}{ Dependent Var: success dummy } \\
\hline & (1) & $(2)$ & (3) & (4) & $(5)$ & $(6)$ & (7) & (8) \\
\hline Covered in week 1 & $\begin{array}{l}0.679^{* * * *} \\
(0.070)\end{array}$ & $\begin{array}{l}0.640^{* * * *} \\
(0.075)\end{array}$ & $\begin{array}{l}0.638^{* * *} \\
(0.069)\end{array}$ & $\begin{array}{l}0.609^{* * *} \\
(0.074)\end{array}$ & $\begin{array}{l}0.545^{* * *} \\
(0.072)\end{array}$ & $\begin{array}{l}0.439^{* * * *} \\
(0.061)\end{array}$ & $\begin{array}{l}0.376^{* * * *} \\
(0.069)\end{array}$ & $\begin{array}{l}0.318^{* * *} \\
(0.060)\end{array}$ \\
\hline Share private pledges & $\begin{array}{c}-0.014 \\
(0.052)\end{array}$ & $\begin{array}{l}-0.013 \\
(0.053)\end{array}$ & $\begin{array}{l}-0.013 \\
(0.051)\end{array}$ & $\begin{array}{c}-0.013 \\
(0.052)\end{array}$ & $\begin{array}{c}0.006 \\
(0.047)\end{array}$ & $\begin{array}{c}0.027 \\
(0.052)\end{array}$ & $\begin{array}{c}0.002 \\
(0.043)\end{array}$ & $\begin{array}{c}0.020 \\
(0.050)\end{array}$ \\
\hline Log campaign goal & $\begin{array}{l}-0.069^{* * *} \\
(0.023)\end{array}$ & $\begin{array}{l}-0.062^{* *} \\
(0.022)\end{array}$ & $\begin{array}{l}-0.087^{* * * *} \\
(0.023)\end{array}$ & $\begin{array}{l}-0.081^{\text {***** }} \\
(0.022)\end{array}$ & $\begin{array}{l}-0.097^{* * *} \\
(0.022)\end{array}$ & $\begin{array}{l}-0.143^{* * * *} \\
(0.021)\end{array}$ & $\begin{array}{l}-0.142^{* * * *} \\
(0.021)\end{array}$ & $\begin{array}{l}-0.172^{* *} \\
(0.020)\end{array}$ \\
\hline Log pre-money valuation & $\begin{array}{c}0.042^{*} \\
(0.025)\end{array}$ & $\begin{array}{c}0.038 \\
(0.025)\end{array}$ & $\begin{array}{c}0.043^{*} \\
(0.025)\end{array}$ & $\begin{array}{c}0.040 \\
(0.024)\end{array}$ & $\begin{array}{c}0.033 \\
(0.023)\end{array}$ & $\begin{array}{c}0.024 \\
(0.021)\end{array}$ & $\begin{array}{c}0.019 \\
(0.020)\end{array}$ & $\begin{array}{c}0.014 \\
(0.018)\end{array}$ \\
\hline \# Entrepreneurs & $\begin{array}{c}0.019^{*} \\
(0.012)\end{array}$ & $\begin{array}{c}0.020^{*} \\
(0.012)\end{array}$ & $\begin{array}{c}0.022^{*} \\
(0.011)\end{array}$ & $\begin{array}{l}0.022^{* *} \\
(0.011)\end{array}$ & $\begin{array}{c}0.021^{*} \\
(0.011)\end{array}$ & $\begin{array}{c}0.007 \\
(0.010)\end{array}$ & $\begin{array}{c}-0.002 \\
(0.010)\end{array}$ & $\begin{array}{c}-0.009 \\
(0.009)\end{array}$ \\
\hline EIS tax relief & $\begin{array}{l}0.068 \\
(0.065)\end{array}$ & $\begin{array}{c}0.063 \\
(0.065)\end{array}$ & $\begin{array}{c}0.050 \\
(0.065)\end{array}$ & $\begin{array}{c}0.046 \\
(0.065)\end{array}$ & $\begin{array}{c}0.057 \\
(0.062)\end{array}$ & $\begin{array}{l}-0.012 \\
(0.058)\end{array}$ & $\begin{array}{c}0.011 \\
(0.054)\end{array}$ & $\begin{array}{l}-0.038 \\
(0.052)\end{array}$ \\
\hline SEIS tax relief & $\begin{array}{c}0.013 \\
(0.059)\end{array}$ & $\begin{array}{c}0.008 \\
(0.058)\end{array}$ & $\begin{array}{l}-0.001 \\
(0.059)\end{array}$ & $\begin{array}{c}-0.005 \\
(0.059)\end{array}$ & $\begin{array}{c}-0.012 \\
(0.056)\end{array}$ & $\begin{array}{c}-0.040 \\
(0.053)\end{array}$ & $\begin{array}{l}-0.024 \\
(0.049)\end{array}$ & $\begin{array}{l}-0.044 \\
(0.048)\end{array}$ \\
\hline Backer success share & & $\begin{array}{l}0.193^{* *} \\
(0.081)\end{array}$ & & $\begin{array}{c}0.151^{*} \\
(0.080)\end{array}$ & $\begin{array}{l}0.206^{* *} \\
(0.078)\end{array}$ & $\begin{array}{c}0.085 \\
(0.068)\end{array}$ & $\begin{array}{l}0.233^{* *} \\
(0.076)\end{array}$ & $\begin{array}{l}0.129^{* *} \\
(0.065)\end{array}$ \\
\hline Backer in top $1 \%$ & & & $\begin{array}{l}0.384^{* * *} \\
(0.075)\end{array}$ & $\begin{array}{l}0.371^{* * *} \\
(0.076)\end{array}$ & $\begin{array}{l}0.351^{* * *} \\
(0.075)\end{array}$ & $\begin{array}{l}0.286^{* * * *} \\
(0.064)\end{array}$ & $\begin{array}{c}0.170^{*} \\
(0.101)\end{array}$ & $\begin{array}{c}0.146^{*} \\
(0.082)\end{array}$ \\
\hline Log median pledge & & & & & $\begin{array}{l}0.071^{* * *} \\
(0.014)\end{array}$ & $\begin{array}{c}0.015 \\
(0.013)\end{array}$ & $\begin{array}{l}0.069^{* * * *} \\
(0.012)\end{array}$ & $\begin{array}{c}0.023^{*} \\
(0.012)\end{array}$ \\
\hline Log max pledge & & & & & & $\begin{array}{l}0.094^{* * * *} \\
(0.009)\end{array}$ & & $\begin{array}{l}0.077^{* * *} \\
(0.010)\end{array}$ \\
\hline \# Backers & & & & & & & $\begin{array}{l}0.002^{* *} \\
(0.001)\end{array}$ & $\begin{array}{l}0.001^{* * *} \\
(0.000) \\
\end{array}$ \\
\hline Observations & 628 & 628 & 628 & 628 & 625 & 625 & 625 & 625 \\
\hline$R^{2}$ & 0.396 & 0.401 & 0.422 & 0.425 & 0.456 & 0.542 & 0.547 & 0.603 \\
\hline Adj. $R^{2}$ & 0.376 & 0.380 & 0.402 & 0.404 & 0.435 & 0.523 & 0.529 & 0.587 \\
\hline Standardized Effect & & & & & & & & \\
\hline Covered in Week 1 & 24.85 & 23.44 & 23.35 & 22.30 & 19.96 & 16.10 & 13.79 & 11.63 \\
\hline Share private pledges & -0.28 & -0.27 & -0.26 & -0.25 & 0.12 & 0.54 & 0.05 & 0.40 \\
\hline Log campaign goal & -6.70 & -5.99 & -8.44 & -7.83 & -9.42 & -13.81 & -13.74 & -16.64 \\
\hline Log pre-money valuation & 4.50 & 4.08 & $\begin{array}{l}4.52 \\
3.78\end{array}$ & $\begin{array}{l}4.19 \\
3.90\end{array}$ & 3.54 & 2.54 & 2.01 & $\begin{array}{r}1.44 \\
-1.65\end{array}$ \\
\hline $\begin{array}{l}\text { \# entrepreneurs } \\
\text { EIS }\end{array}$ & $\begin{array}{l}3.40 \\
3.04\end{array}$ & $\begin{array}{l}3.56 \\
2.77\end{array}$ & $\begin{array}{l}3.78 \\
2.22\end{array}$ & $\begin{array}{l}3.90 \\
2.04\end{array}$ & $\begin{array}{l}3.63 \\
2.52\end{array}$ & $\begin{array}{c}1.30 \\
-0.54\end{array}$ & $\begin{array}{c}-0.39 \\
0.51\end{array}$ & $\begin{array}{l}-1.65 \\
-1.68\end{array}$ \\
\hline SEIS & 0.64 & 0.37 & -0.06 & -0.25 & -0.59 & -1.91 & -1.13 & -2.12 \\
\hline Backer success share & & 3.84 & & 3.00 & 4.09 & 1.68 & 4.63 & 2.55 \\
\hline Backer in top $1 \%$ & & & 8.01 & 7.74 & 7.33 & 5.98 & 3.55 & 3.06 \\
\hline Log median pledge & & & & & 7.55 & 1.62 & 7.27 & 2.44 \\
\hline Log max pledge & & & & & & 21.64 & & 17.78 \\
\hline \# backers & & & & & & & 20.12 & 16.81 \\
\hline
\end{tabular}

Notes: robust standard errors in parenthesis. Year-quarter fixed effects included in all models, but not reported. The standardized effects are computed as the effect of an increase of one standard deviation of the relevant variable on the probability of success (in percentage points). 
Table 4: Percent raised: OLS and quantile regression

\begin{tabular}{|c|c|c|c|c|c|c|}
\hline & \multicolumn{6}{|c|}{ Dependent Var: percent raised } \\
\hline & OLS & Q10 & Q25 & Q50 & Q75 & Q90 \\
\hline Covered in week 1 & $\begin{array}{l}0.725^{* * *} \\
(0.100)\end{array}$ & $\begin{array}{l}0.827^{* * *} \\
(0.011)\end{array}$ & $\begin{array}{l}0.798^{* * *} \\
(0.028)\end{array}$ & $\begin{array}{l}0.701^{* * *} \\
(0.068)\end{array}$ & $\begin{array}{l}0.598^{* * * *} \\
(0.066)\end{array}$ & $\begin{array}{l}0.962^{* * * *} \\
(0.136)\end{array}$ \\
\hline Share private pledges & $\begin{array}{c}-0.010 \\
(0.056)\end{array}$ & $\begin{array}{l}-0.003 \\
(0.016)\end{array}$ & $\begin{array}{l}-0.010 \\
(0.043)\end{array}$ & $\begin{array}{l}-0.006 \\
(0.102)\end{array}$ & $\begin{array}{c}0.015 \\
(0.099)\end{array}$ & $\begin{array}{c}0.027 \\
(0.205)\end{array}$ \\
\hline Log campaign goal & $\begin{array}{l}-0.233^{* * * *} \\
(0.026)\end{array}$ & $\begin{array}{l}-0.050^{* * * *} \\
(0.005)\end{array}$ & $\begin{array}{l}-0.065^{* * * *} \\
(0.013)\end{array}$ & $\begin{array}{l}-0.110^{* * * *} \\
(0.031)\end{array}$ & $\begin{array}{l}-0.196^{* * *} \\
(0.030)\end{array}$ & $\begin{array}{l}-0.201^{* *} \\
(0.062)\end{array}$ \\
\hline Log pre-money valuation & $\begin{array}{c}0.021 \\
(0.023)\end{array}$ & $\begin{array}{c}0.006 \\
(0.005)\end{array}$ & $\begin{array}{c}0.006 \\
(0.013)\end{array}$ & $\begin{array}{c}0.010 \\
(0.030)\end{array}$ & $\begin{array}{c}0.045 \\
(0.029)\end{array}$ & $\begin{array}{c}0.020 \\
(0.061)\end{array}$ \\
\hline \# Entrepreneurs & $\begin{array}{l}-0.023^{* *} \\
(0.012)\end{array}$ & $\begin{array}{c}0.002 \\
(0.002)\end{array}$ & $\begin{array}{l}-0.004 \\
(0.006)\end{array}$ & $\begin{array}{l}-0.013 \\
(0.014)\end{array}$ & $\begin{array}{l}-0.020 \\
(0.013)\end{array}$ & $\begin{array}{l}-0.029 \\
(0.028)\end{array}$ \\
\hline EIS tax relief & $\begin{array}{c}0.048 \\
(0.055)\end{array}$ & $\begin{array}{l}-0.006 \\
(0.012)\end{array}$ & $\begin{array}{l}-0.003 \\
(0.033)\end{array}$ & $\begin{array}{c}0.021 \\
(0.079)\end{array}$ & $\begin{array}{c}0.066 \\
(0.076)\end{array}$ & $\begin{array}{c}0.000 \\
(0.158)\end{array}$ \\
\hline SEIS tax relief & $\begin{array}{c}0.017 \\
(0.046)\end{array}$ & $\begin{array}{l}-0.005 \\
(0.012)\end{array}$ & $\begin{array}{l}-0.005 \\
(0.031)\end{array}$ & $\begin{array}{c}0.041 \\
(0.075)\end{array}$ & $\begin{array}{c}0.083 \\
(0.073)\end{array}$ & $\begin{array}{c}0.044 \\
(0.150)\end{array}$ \\
\hline Backer success share & $\begin{array}{c}-0.021 \\
(0.085)\end{array}$ & $\begin{array}{c}0.007 \\
(0.018)\end{array}$ & $\begin{array}{c}-0.016 \\
(0.046)\end{array}$ & $\begin{array}{c}-0.016 \\
(0.111)\end{array}$ & $\begin{array}{l}-0.011 \\
(0.108)\end{array}$ & $\begin{array}{c}0.015 \\
(0.223)\end{array}$ \\
\hline Backer in top $1 \%$ & $\begin{array}{c}0.149 \\
(0.123)\end{array}$ & $\begin{array}{c}0.014 \\
(0.015)\end{array}$ & $\begin{array}{c}0.041 \\
(0.041)\end{array}$ & $\begin{array}{c}0.115 \\
(0.097)\end{array}$ & $\begin{array}{c}0.182^{*} \\
(0.095)\end{array}$ & $\begin{array}{c}0.099 \\
(0.196)\end{array}$ \\
\hline Log median pledge & $\begin{array}{c}-0.002 \\
(0.015)\end{array}$ & $\begin{array}{c}0.002 \\
(0.003)\end{array}$ & $\begin{array}{c}0.004 \\
(0.009)\end{array}$ & $\begin{array}{c}0.008 \\
(0.021)\end{array}$ & $\begin{array}{c}0.016 \\
(0.021)\end{array}$ & $\begin{array}{c}-0.008 \\
(0.043)\end{array}$ \\
\hline Log max pledge & $\begin{array}{l}0.108^{* * * *} \\
(0.012)\end{array}$ & $\begin{array}{l}0.025^{* * *} \\
(0.002)\end{array}$ & $\begin{array}{l}0.033^{* * * *} \\
(0.005)\end{array}$ & $\begin{array}{l}0.051^{* * * *} \\
(0.013)\end{array}$ & $\begin{array}{l}0.056^{* * * *} \\
(0.013)\end{array}$ & $\begin{array}{l}0.068^{* *} \\
(0.026)\end{array}$ \\
\hline \# Backers & $\begin{array}{l}0.002^{* * *} \\
(0.001)\end{array}$ & $\begin{array}{l}0.001^{* * *} \\
(0.000)\end{array}$ & $\begin{array}{l}0.002^{* * *} \\
(0.000)\end{array}$ & $\begin{array}{l}0.003^{* * * *} \\
(0.000)\end{array}$ & $\begin{array}{l}0.005^{* * * *} \\
(0.000)\end{array}$ & $\begin{array}{l}0.005^{* * * *} \\
(0.000)\end{array}$ \\
\hline $\begin{array}{l}\text { Observations } \\
R^{2} \\
\text { Standardized Effect }\end{array}$ & $\begin{array}{c}625 \\
0.733\end{array}$ & 625 & 625 & 625 & 625 & 625 \\
\hline Covered in Week 1 & 26.57 & 30.29 & 29.24 & 25.66 & 21.89 & 35.24 \\
\hline Share private pledges & -0.20 & -0.07 & -0.20 & -0.12 & 0.30 & 0.55 \\
\hline Log campaign goal & -22.55 & -4.84 & -6.26 & -10.64 & -18.94 & -19.50 \\
\hline Log pre-money valuation & 2.25 & 0.64 & 0.60 & 1.01 & 4.82 & 2.15 \\
\hline \# entrepreneurs & -4.01 & 0.29 & -0.62 & -2.25 & -3.51 & -5.09 \\
\hline EIS & 2.11 & -0.28 & -0.13 & 0.94 & 2.94 & 0.02 \\
\hline SEIS & 0.81 & -0.22 & -0.24 & 1.96 & 3.97 & 2.08 \\
\hline Backer success share & -0.41 & 0.14 & -0.32 & -0.32 & -0.22 & 0.29 \\
\hline Backer in top $1 \%$ & 3.12 & 0.29 & 0.86 & 2.40 & 3.81 & 2.07 \\
\hline Log median pledge & -0.17 & 0.19 & 0.44 & 0.89 & 1.74 & -0.80 \\
\hline Log max pledge & 24.99 & 5.84 & 7.63 & 11.67 & 13.00 & 15.60 \\
\hline \# backers & 25.22 & 11.98 & 20.06 & 39.43 & 59.29 & 61.00 \\
\hline
\end{tabular}

Notes: Standard errors are reported in parenthesis. Year-quarter fixed effects included in all models, but not reported. The standardized effects are computed as the effect of an increase of one standard deviation of the relevant variable on the average/quantile share of the campaign's goal raised (in percentage points). 
Table 5: Percent raised during first week

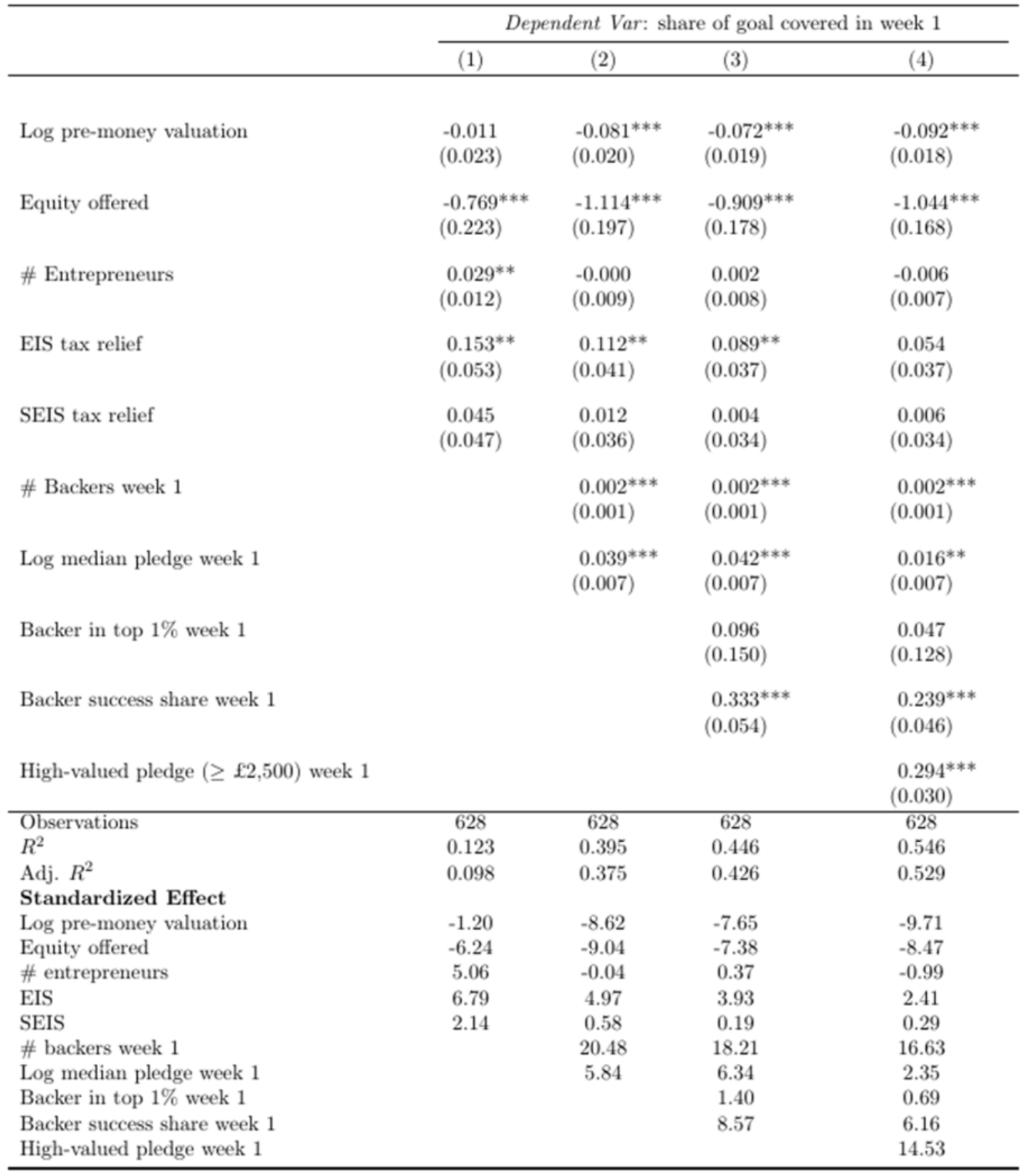

Notes: Standard errors are reported in parenthesis. Year-quarter fixed effects included in all models, but not reported. The standardized effects are computed as the effect of an increase of one standard deviation of the relevant variable on the average share of the campaign's goal raised during the first week (in percentage points). 
Table 6: Geographical distribution of backers

\begin{tabular}{lcccc}
\hline \multicolumn{1}{c}{ City } & Country & $\begin{array}{c}\text { Share of } \\
\text { Investors }\end{array}$ & $\begin{array}{c}\text { Share of } \\
\text { Pledges } \\
(\mathrm{f})\end{array}$ & $\begin{array}{c}\text { Share of } \\
\text { Pledges } \\
(\#)\end{array}$ \\
\hline London & United Kingdom & 24.49 & 38.58 & 25.94 \\
N/A & United Kingdom & 6.63 & 7.03 & 2.33 \\
Bristol & United Kingdom & 1.26 & 0.91 & 1.22 \\
Cardiff & United Kingdom & 0.69 & 0.31 & 0.37 \\
Manchester & United Kingdom & 0.68 & 0.27 & 0.45 \\
Edinburgh & United Kingdom & 0.62 & 0.35 & 0.39 \\
Reading & United Kingdom & 0.59 & 0.35 & 0.73 \\
Maidstone & United Kingdom & 0.58 & 0.38 & 0.32 \\
Cambridge & United Kingdom & 0.55 & 0.36 & 0.70 \\
Ashford & United Kingdom & 0.52 & 0.14 & 0.45 \\
Tunbridge Wells & United Kingdom & 0.52 & 2.24 & 0.37 \\
Nottingham & United Kingdom & 0.47 & 0.48 & 0.55 \\
Southampton & United Kingdom & 0.42 & 0.10 & 0.44 \\
Leeds & United Kingdom & 0.42 & 0.17 & 0.40 \\
Brighton & United Kingdom & 0.41 & 0.21 & 0.31 \\
Milton Keynes & United Kingdom & 0.40 & 0.96 & 0.43 \\
Birmingham & United Kingdom & 0.37 & 0.21 & 0.45 \\
Bath & United Kingdom & 0.37 & 1.01 & 0.29 \\
\hline & & & &
\end{tabular}


Figure 1: Mean campaign goal for new campaigns

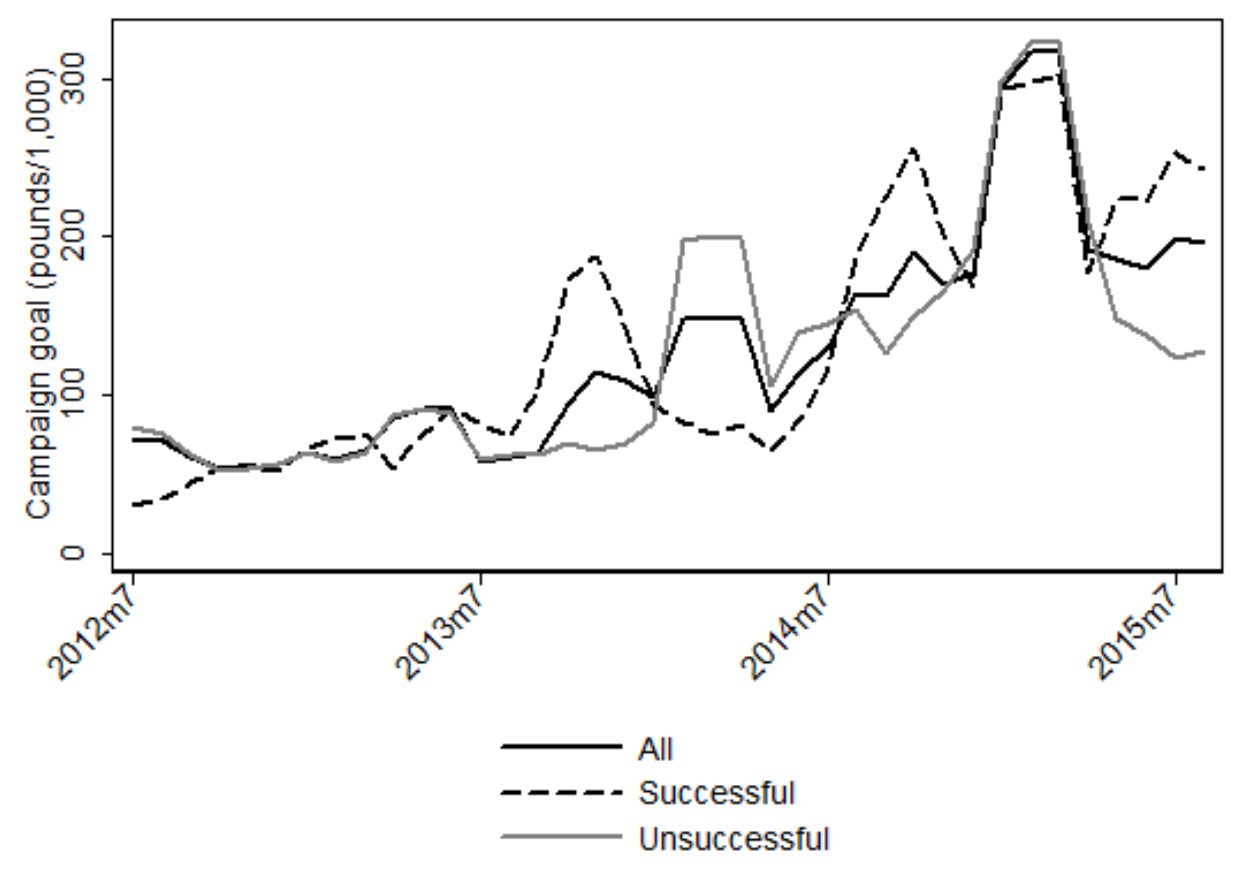

Notes: Series correspond to a 3-month moving average.

Figure 2: Total amount pledged per month

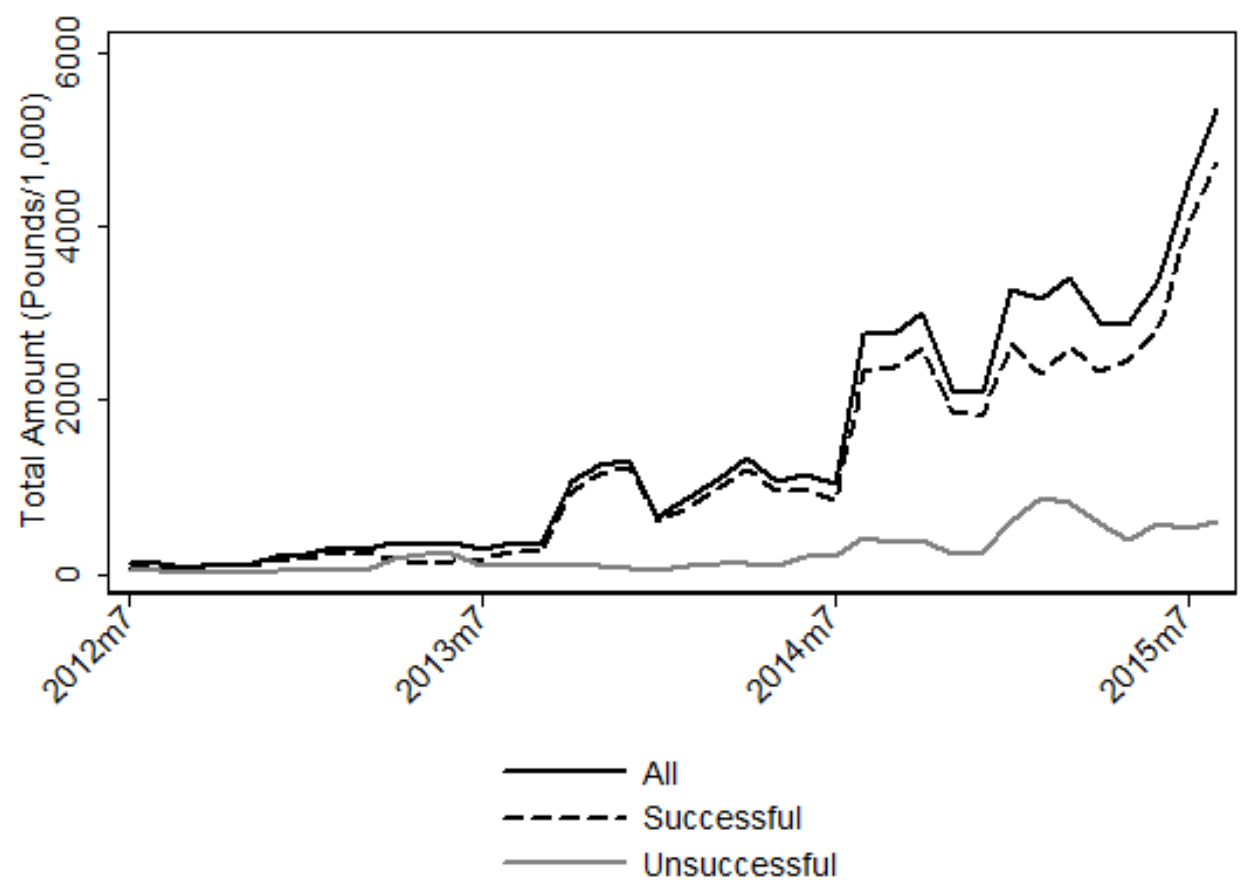

Notes: Series correspond to a 3-month moving average. 
Figure 3: Timing of Cumulative Investments
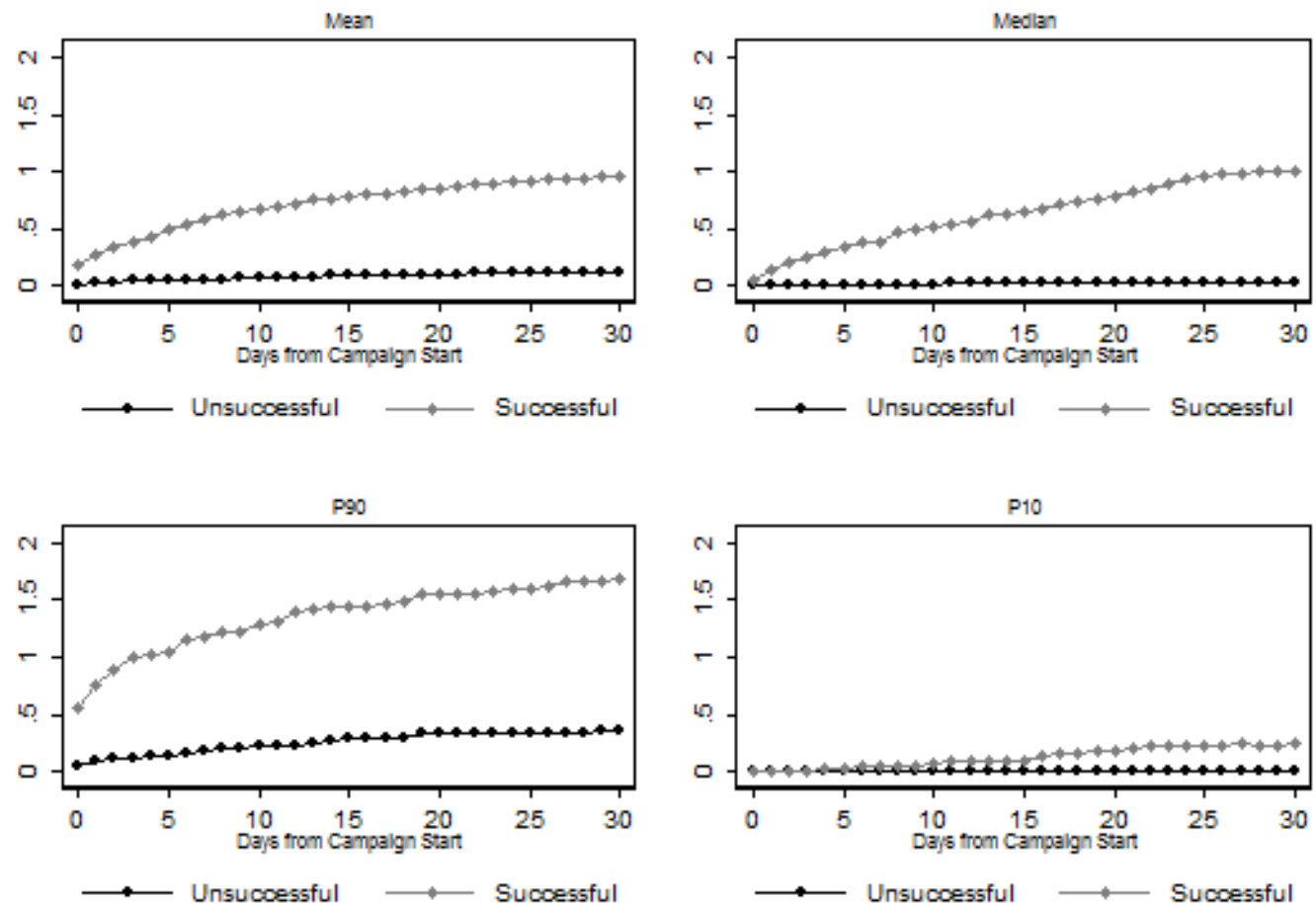

Figure 4: Backers per campaign by calendar month

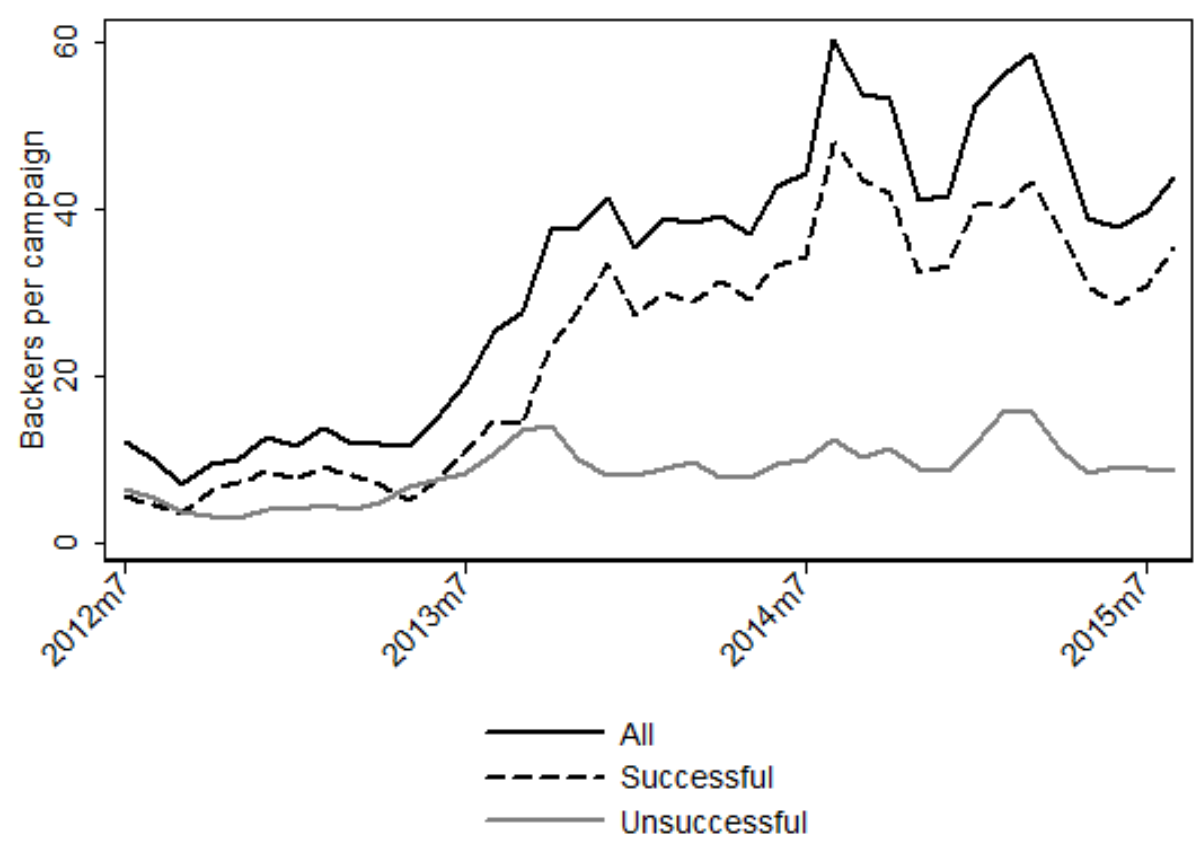

Notes: Series correspond to a 3-month moving average. 
Figure 5: Mean amount pledged per month

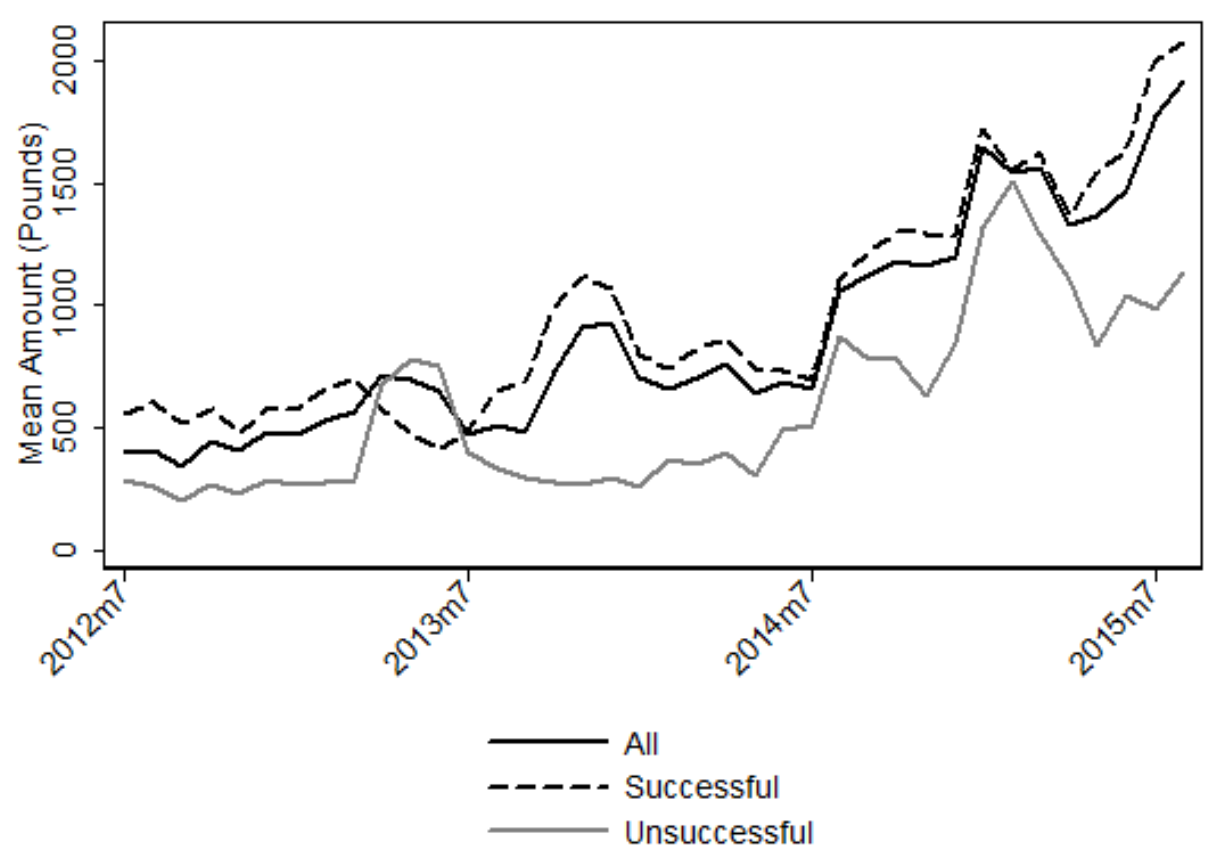

Notes: Series correspond to a 3-month moving average.

Figure 6: Percentage of campaigns that reach the goal each month

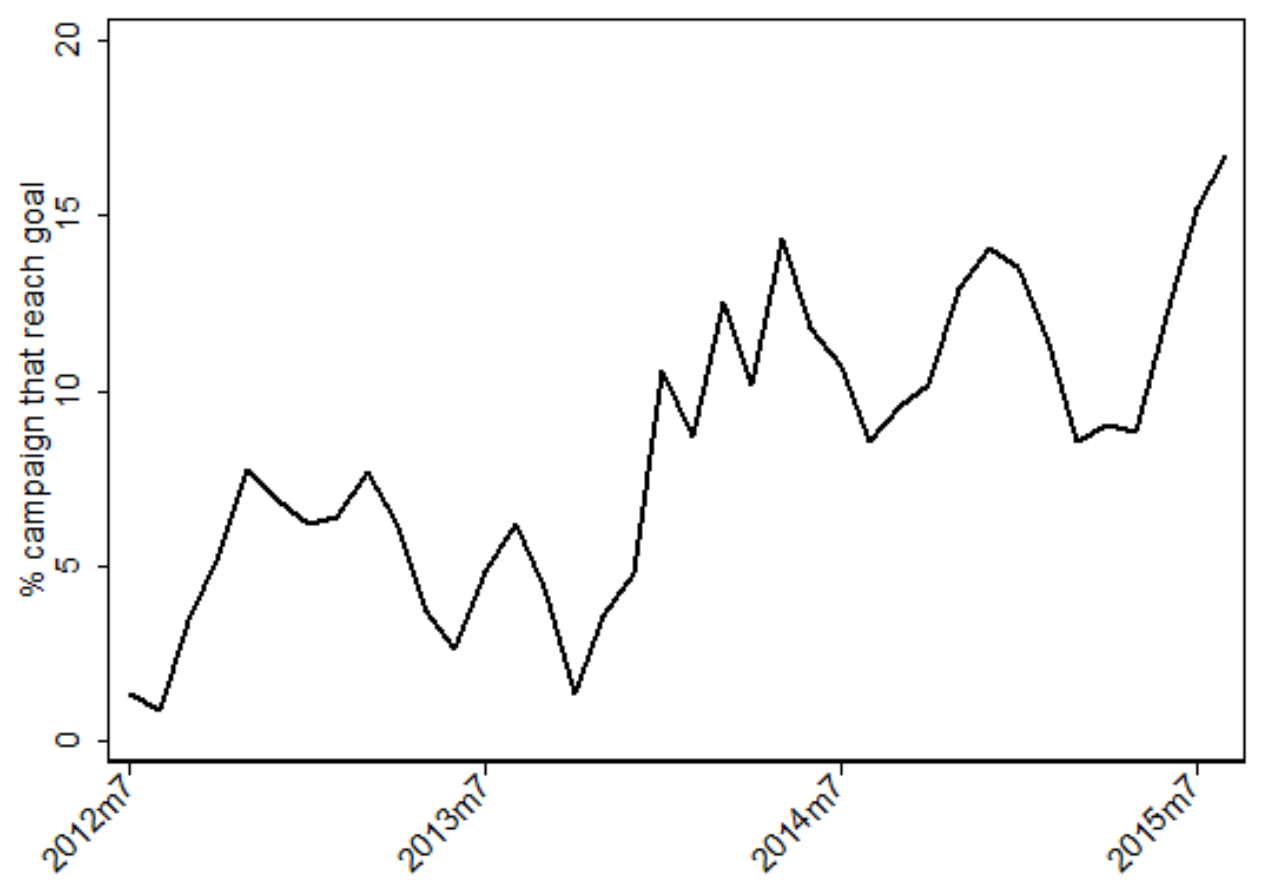

Notes: Series correspond to a 3-month moving average. 


\section{References}

Agrawal, A., Catalini, C. and Goldfarb, A. (2011). The Geography of Crowdfunding. NBER Working Paper Series 16820.

Agrawal, A., Catalini, C. and Goldfarb, A. (2014). Some Simple Economics of Crowdfunding. NBER Innovation Policy \& the Economy 14(1): pp. 63-97.

Åstebro, T., M. Fernandez Sierra, and N. Vulkan (2015). “Herding in Equity Crowdfunding”, working paper, HEC Paris.

Banerjee, A. (1992). A Simple Model of Herd Behavior. The Quarterly Journal of Economics 107: pp. 797-817.

Beauhurst, (2015). "The Deal, Q3 2015, review of the U.K equity landscape" www.beauhurst.com

Beauhurst, (2016). "Crowdfunding: going from strenth to strengh" www.beauhurst.com

Belleflamme, P. N. Omrani and M. Peitz (2015). The Economics of Crowdfunding Platforms. CORE DISCUSSION PAPER, 2015/15, Université catholique de Louvain.

Belleflamme, P., Lambert, T. and Schwienbacher, A. (2014). Crowdfunding: Tapping the Right Crowd. Journal of Business Venturing 29(14): pp. 585-609.

Chari, V. and Kehoe, P. (2004). Financial Crisis as Herds: Overturning the Critiques. Journal of Economic Theory 119(1): pp. 128-150.

Colombo, M. G., C. Franzoni, and C. Rossi-Lamastra (2015). Internal Social Capital and the Attraction of Early Contributions in Crowdfunding. Entrepreneurship Theory and Practice 39(1): 75-100.

Cumming, Douglas, and Na Dai. (2010). Local Bias in Venture Capital Investments. Journal of Empirical Finance 17(3): 362-380.

Gompers, P. (1995). Optimal Investment, Monitoring, and the Staging of Venture Capital. Journal of Finance 50, 1461-1489.

Kim, K. and Viswanathan, S. (2014). "The Experts in the Crowd: The Role of Reputable Investors in a Crowdfunding Market." The 41st Research Conference on Communication, Information and Internet Policy.

Kim, Jin-Hyuk, P. W. Newberry, and C. Qiu (2015). "An Empirical Analysis of a Crowdfunding Platform." Available at SSRN.

Kuppuswamy, Venkat and Bayus, Barry L., (2015) Crowdfunding Creative Ideas: The Dynamics of Project Backers in Kickstarter. UNC Kenan-Flagler Research Paper No. 2013-15. Available at SSRN:http://ssrn.com/abstract=2234765 or http://dx.doi.org/10.2139/ssrn.2234765

Massolution, 2013. 2013 Crowdfunding Report. 
Massolution (2015). 2015CF Crowdfunding Industry Report, see

http://reports.crowdsourcing.org/index.php?route=product/product\&product id=54\#oid=1001 23 banner 38

Mollick, E. (2014). The Dynamics of Crowdfunding: An Exploratory Study. Journal of Business Venturing 29(1): pp. 1-16.

The World Bank (2013). Crowdfunding's Potential for the Developing World. infoDev, Finance and Private Sector Development Department. Washington, DC: World Bank.

Welch, I. (1992). Sequential Sales, Learning, and Cascades. The Journal of Finance 47(2): pp. 695-732.

Zhang, J. and Liu, P. (2012). Rational Herding in Microloan Markets. Management Science 58(5): pp. 892-912.

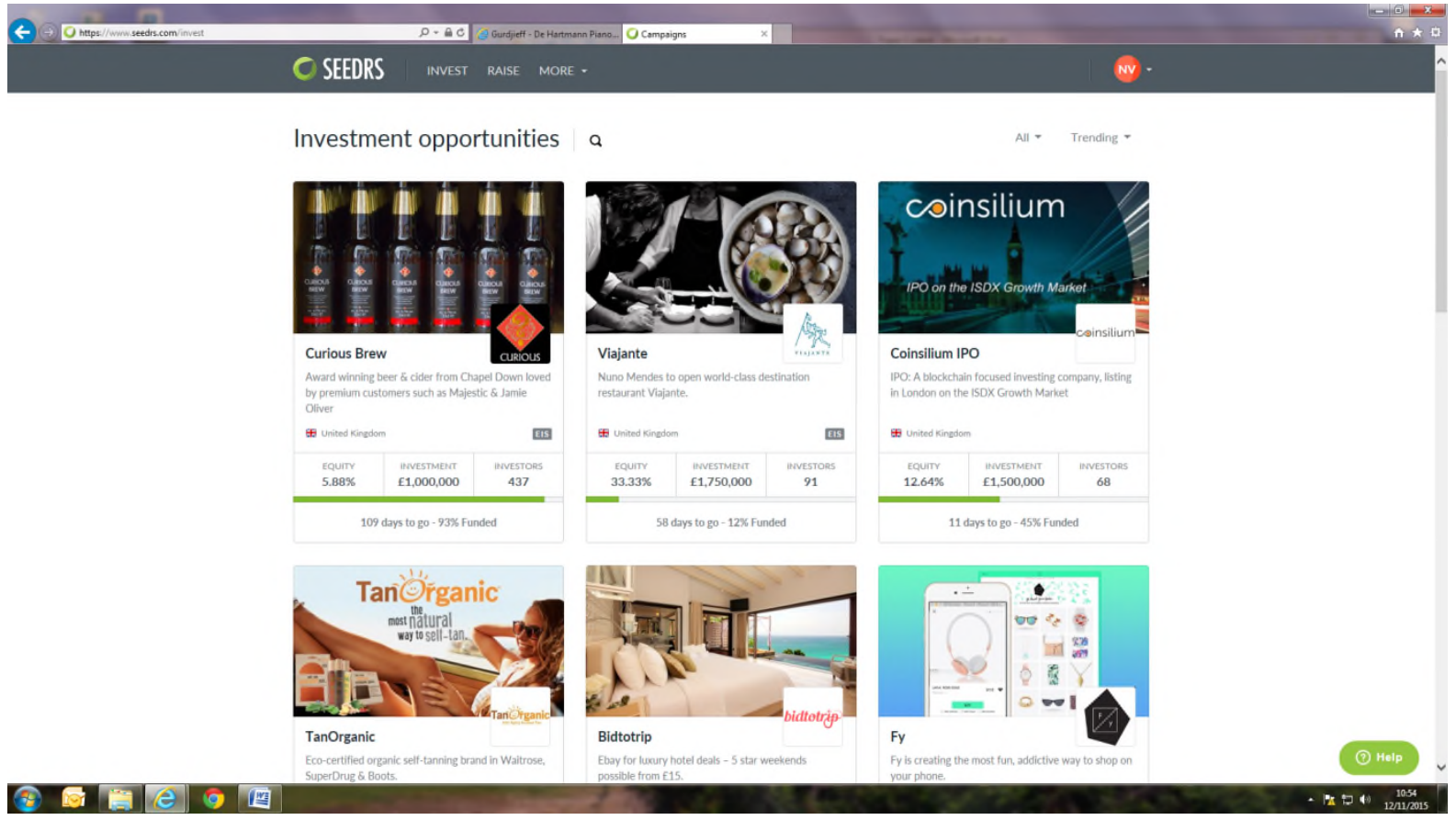




\section{Appendix.}

Table A1: Probability of success. Probit Model

\begin{tabular}{|c|c|c|c|c|c|c|c|c|}
\hline & \multicolumn{8}{|c|}{ Dependent Var: success dummy } \\
\hline & (1) & $(2)$ & (3) & (4) & (5) & (6) & (7) & (8) \\
\hline Covered in week 1 & $\begin{array}{l}0.966^{* * * *} \\
(0.108)\end{array}$ & $\begin{array}{l}0.940^{* * * *} \\
(0.110)\end{array}$ & $\begin{array}{l}0.909^{* * *} \\
(0.104)\end{array}$ & $\begin{array}{l}0.891^{* * * *} \\
(0.105)\end{array}$ & $\begin{array}{l}0.778^{* * *} \\
(0.107)\end{array}$ & $\begin{array}{l}0.314^{* * * *} \\
(0.072)\end{array}$ & $\begin{array}{l}0.344^{* * *} \\
(0.057)\end{array}$ & $\begin{array}{l}0.129^{* * * *} \\
(0.036)\end{array}$ \\
\hline Share private pledges & $\begin{array}{c}0.021 \\
(0.065)\end{array}$ & $\begin{array}{c}0.027 \\
(0.066)\end{array}$ & $\begin{array}{c}0.019 \\
(0.064)\end{array}$ & $\begin{array}{c}0.024 \\
(0.065)\end{array}$ & $\begin{array}{c}0.019 \\
(0.053)\end{array}$ & $\begin{array}{c}0.061 \\
(0.079)\end{array}$ & $\begin{array}{c}0.041 \\
(0.044)\end{array}$ & $\begin{array}{c}0.042 \\
(0.060)\end{array}$ \\
\hline Log campaign goal & $\begin{array}{l}-0.081^{* * * *} \\
(0.021)\end{array}$ & $\begin{array}{l}-0.079^{* * * *} \\
(0.021)\end{array}$ & $\begin{array}{l}-0.087^{* * * *} \\
(0.021)\end{array}$ & $\begin{array}{l}-0.086^{* * * *} \\
(0.021)\end{array}$ & $\begin{array}{l}-0.104^{* * *} \\
(0.020)\end{array}$ & $\begin{array}{l}-0.180^{* * * *} \\
(0.020)\end{array}$ & $\begin{array}{l}-0.098^{* * *} \\
(0.016)\end{array}$ & $\begin{array}{l}-0.137^{* * * x} \\
(0.017)\end{array}$ \\
\hline Log pre-money valuation & $\begin{array}{c}0.033 \\
(0.022)\end{array}$ & $\begin{array}{c}0.032 \\
(0.022)\end{array}$ & $\begin{array}{c}0.030 \\
(0.022)\end{array}$ & $\begin{array}{c}0.029 \\
(0.022)\end{array}$ & $\begin{array}{c}0.026 \\
(0.022)\end{array}$ & $\begin{array}{c}-0.008 \\
(0.018)\end{array}$ & $\begin{array}{l}-0.013 \\
(0.015)\end{array}$ & $\begin{array}{l}-0.034^{* *} \\
(0.012)\end{array}$ \\
\hline \# Entrepreneurs & $\begin{array}{c}0.016^{*} \\
(0.010)\end{array}$ & $\begin{array}{c}0.016^{*} \\
(0.009)\end{array}$ & $\begin{array}{c}0.016^{*} \\
(0.009)\end{array}$ & $\begin{array}{c}0.016^{*} \\
(0.009)\end{array}$ & $\begin{array}{c}0.015^{*} \\
(0.009)\end{array}$ & $\begin{array}{c}0.013^{*} \\
(0.007)\end{array}$ & $\begin{array}{c}0.007 \\
(0.006)\end{array}$ & $\begin{array}{c}0.007 \\
(0.005)\end{array}$ \\
\hline EIS tax relief & $\begin{array}{c}0.063 \\
(0.050)\end{array}$ & $\begin{array}{c}0.062 \\
(0.050)\end{array}$ & $\begin{array}{c}0.040 \\
(0.049)\end{array}$ & $\begin{array}{c}0.040 \\
(0.049)\end{array}$ & $\begin{array}{c}0.044 \\
(0.045)\end{array}$ & $\begin{array}{c}-0.028 \\
(0.038)\end{array}$ & $\begin{array}{l}-0.050 \\
(0.035)\end{array}$ & $\begin{array}{l}-0.051^{*} \\
(0.027)\end{array}$ \\
\hline SEIS tax relief & $\begin{array}{c}0.004 \\
(0.044)\end{array}$ & $\begin{array}{c}0.002 \\
(0.044)\end{array}$ & $\begin{array}{l}-0.013 \\
(0.043)\end{array}$ & $\begin{array}{c}-0.015 \\
(0.043)\end{array}$ & $\begin{array}{l}-0.035 \\
(0.040)\end{array}$ & $\begin{array}{l}-0.083^{* *} \\
(0.037)\end{array}$ & $\begin{array}{l}-0.035 \\
(0.032)\end{array}$ & $\begin{array}{l}-0.043 \\
(0.027)\end{array}$ \\
\hline Backer success share & & $\begin{array}{c}0.094 \\
(0.070)\end{array}$ & & $\begin{array}{c}0.070 \\
(0.068)\end{array}$ & $\begin{array}{l}0.166^{* *} \\
(0.065)\end{array}$ & $\begin{array}{l}0.134^{* *} \\
(0.065)\end{array}$ & $\begin{array}{c}0.034 \\
(0.052)\end{array}$ & $\begin{array}{c}0.052 \\
(0.045)\end{array}$ \\
\hline Backer in top $1 \%$ & & & $\begin{array}{l}0.278^{* * *} \\
(0.077)\end{array}$ & $\begin{array}{l}0.273^{* * *} \\
(0.077)\end{array}$ & $\begin{array}{l}0.249^{* * *} \\
(0.072)\end{array}$ & $\begin{array}{l}0.178^{* * * *} \\
(0.051)\end{array}$ & $\begin{array}{c}0.056 \\
(0.072)\end{array}$ & $\begin{array}{c}0.011 \\
(0.033)\end{array}$ \\
\hline Log median pledge & & & & & $\begin{array}{l}0.062^{* * * *} \\
(0.013)\end{array}$ & $\begin{array}{l}0.047^{* * * *} \\
(0.012)\end{array}$ & $\begin{array}{l}0.043^{* * * *} \\
(0.009)\end{array}$ & $\begin{array}{l}0.038^{* * * *} \\
(0.008)\end{array}$ \\
\hline Log max pledge & & & & & & $\begin{array}{l}0.134^{\text {****}} \\
(0.011)\end{array}$ & & $\begin{array}{l}0.082^{* * *} \\
(0.011)\end{array}$ \\
\hline \# Backers & & & & & & & $\begin{array}{l}0.002^{* * * *} \\
(0.000)\end{array}$ & $\begin{array}{l}0.002^{* * * *} \\
(0.000) \\
\end{array}$ \\
\hline $\begin{array}{l}\text { Observations } \\
\text { Standardized Effect }\end{array}$ & 627 & 627 & 627 & 627 & 624 & 624 & 624 & 624 \\
\hline Covered in Week 1 & 35.378 & 34.418 & 33.296 & 32.619 & 28.491 & 11.484 & 12.616 & 4.708 \\
\hline Share private pledges & 0.43 & 0.55 & 0.39 & 0.48 & 0.37 & 1.22 & 0.82 & 0.84 \\
\hline Log campaign goal & -7.87 & -7.67 & -8.40 & -8.27 & -10.07 & -17.37 & -9.47 & -13.26 \\
\hline $\begin{array}{l}\text { Log pre-money valuation } \\
\text { \# entrepreneurs }\end{array}$ & $\begin{array}{l}3.54 \\
2.76\end{array}$ & $\begin{array}{l}3.42 \\
2.86\end{array}$ & $\begin{array}{l}3.20 \\
2.82\end{array}$ & $\begin{array}{l}3.12 \\
2.87\end{array}$ & $\begin{array}{l}2.72 \\
2.67\end{array}$ & $\begin{array}{c}-0.83 \\
2.30\end{array}$ & $\begin{array}{r}-1.39 \\
1.16\end{array}$ & $\begin{array}{r}-3.63 \\
1.27\end{array}$ \\
\hline EIS & 2.77 & 2.74 & 1.76 & 1.75 & 1.96 & -1.24 & -2.21 & -2.25 \\
\hline SEIS & 0.18 & 0.09 & -0.64 & -0.71 & -1.66 & -3.95 & -1.69 & -2.08 \\
\hline Backer success share & & 1.87 & & 1.39 & 3.29 & 2.65 & 0.68 & 1.04 \\
\hline Backer in top $1 \%$ & & & 5.81 & 5.71 & 5.20 & 3.72 & 1.18 & 0.23 \\
\hline Log median pledge & & & & & 6.59 & 4.95 & 4.52 & 4.02 \\
\hline Log max pledge & & & & & & 30.84 & & 18.83 \\
\hline \# backers & & & & & & & 25.41 & 17.27 \\
\hline
\end{tabular}

Notes: reported coefficients correspond to the average marginal effects after the estimation of a probit model. Standard errors are reported in parenthesis. Year-quarter fixed effects included in all models, but not reported. The standardized effects are computed as the average marginal effect of an increase of one standard deviation of the relevant variable on the probability of success (in percentage points). 
Table A2: Pre-money valuation

Log pre-money valuation

Log campaign goal

\begin{tabular}{lcc} 
Equity offered & $-4.256^{* * *}$ & $4.504^{* * *}$ \\
& $(0.527)$ & $(0.460)$ \\
\# Entrepreneurs & $0.114^{* * *}$ & $0.126^{* * *}$ \\
& $(0.023)$ & $(0.024)$ \\
EIS tax relief & $0.349^{* *}$ & $0.302^{* *}$ \\
& $(0.145)$ & $(0.131)$ \\
SEIS tax relief & $-0.609^{* * *}$ & $-0.574^{* * *}$ \\
& $(0.141)$ & $(0.121)$ \\
\hline$N$ & 628 & 636 \\
$R^{2}$ & 0.587 & 0.441 \\
\hline
\end{tabular}

Notes: Standard errors are reported in parenthesis. 